Pedagogía y Saberes No. 49

Universidad Pedagógica Nacional

Facultad de Educación. 2018, pp.127-135

\title{
¿Qué cosa es mirar? Aprendendo a ver com pessoas que não veem (apenas) com os olhos
}

\section{Artículo de sistematización de experiencias}

¿Qué cosa es mirar? Aprendiendo a ver con personas que no ven (únicamente) con los ojos What is to look? Learning to See with People Who Don't See (Only) with the Eyes

Para citar este artículo:

Macambira, L. (2018). Qué cosa es mirar? Aprendendo a ver com pessoas que não veem (apenas) com os olhos. Pedagogía y Saberes, 49, 127-135.

* Este artigo é uma reflexão que se desdobra da pesquisa realizada durante o curso de Mestrado em Educação pelo Programa de Pós-Graduação em Educação: Processos Formativos e Desigualdades Sociais da Faculdade de Formação de Professores da Universidade do Estado do Rio de Janeiro (FFP-UERJ), com bolsa de Demanda Social pela Coordenação de Aperfeiçoamento de Pessoal de Nível Superior (CAPES), orientada pela Prof a Drª Anelice Ribetto. A dissertação defendida em fevereiro de 2017, intitula-se por "Encontrar(se), (não)ver(se), diferir(se): Platôs para pensar a educação de pessoas que não veem (apenas) com os olhos".

** Estudiante Universidade Federal Fluminense. Magister en educación e investigadora del grupo LEAM-Laboratório de Estudos e Aprontos Multimídia: Relações étnico-raciais na cultura digital. Coletivo Diferenças e Alteridades na Educação. Correo electrónico: leidianesamacambira@gmail.com Código ORCID: http://orcid.org/0000-0001-9073-2448 


\title{
Resumo
}

Este escrito busca refletir as experiências de pesquisa produzidas a partir de encontros entre pessoas que não veem (apenas) com os olhos. Através do método da cartografia, compomos esta trama investigativa. Interpelados pela pergunta “¿Qué cosa es mirar?", produzimos a cada encontro, sentidos outros para o ver, o não ver e o cegar. Portanto, trata-se de um texto ensaístico que junto a autores como Saramago, Castañeda, Larrosa, dentre outros, busca pensar a visão e seus atravessamentos em nossa formação. Este artigo narra essa experiência e enuncia um desejo: seguir conversando com outras pessoas dispostas a fazer a mesma pergunta colocada no título.

\section{Palavras-chave}

imagem; cegueira; deficiência visual; formação; cartografia

\begin{abstract}
This paper seeks to reflect on research experiences produced from encounters between people who do not see (only) with their eyes and, using cartography as a method, we compiled this research. Driven by the question "what is it to look?," we gave other meanings to seeing, not seeing, and blind. Therefore, this is an essay text that, based on authors such as Saramago, Castañeda, Larrosa, among others, seeks to think about vision and its presence in our education. This article narrates that experience and states a desire to continue talking with other people willing to ask the same question from the title.
\end{abstract}

\section{Keywords}

image; blindness; visual difficulty; training; mapping

\section{Resumen}

Este escrito busca reflexionar sobre las experiencias de investigación producidas a partir de encuentros entre personas que no ven (únicamente) con los ojos. A través de la cartografía como método, compusimos esta trama investigativa. Interpelados por la pregunta “iqué cosa es mirar?", produjimos a cada encuentro, otros significados para ver, no ver y cegar. Por lo tanto, este texto de carácter ensayístico que, con base en autores como Saramago, Castañeda, Larrosa, entre otros, busca pensar la visión y su presencia en nuestra formación. Este artículo narra esa experiencia y enuncia un deseo: seguir conversando con otras personas dispuestas a hacer la misma pregunta realizada en el título.

\section{Palabras clave}

imagen; ceguera; dificultad visual; formación; cartografía 
Nas linhas a seguir pretendo narrar as experiências de ver e não ver com pessoas que não veem (apenas) com os olhos. Elas se tornaram cegas ao longo de suas vidas e, atualmente, fazem reabilitação no Instituto Benjamin Constant, uma instituição pública brasileira, situada na cidade do Rio de Janeiro, referência na educação e reabilitação de pessoas cegas e com baixa visão.

A pesquisa completa encontra-se na dissertação intitulada "Encontrar(se), não ver(se), diferir(se): platôs para pensar a educação de pessoas que não veem (apenas) com os olhos"1. Nela, busquei conhecer, através de encontros, os múltiplos modos de ver de pessoas que resistem a este mundo saturado de profusões visuais e fazem (re)existir mundo outros possíveis.

Imersa nestes mundos-outros, percebi outras dimensões do visível e as múltiplas formas de cegueiras entre pessoas que se consideram ser videntes, ou seja, pessoas que, por terem o "pleno" funcionamento do globo ocular, acreditam enxergar "bem". Percebi minha cegueira, ainda que tivesse olhos. Percebi, assim como os primeiros homens e mulheres narrados no conto zapatista a seguir, que temos olhos, mas não sabemos ver.

Portanto, as linhas a seguir, representam um desejo: entremear conversas entre algumas pessoas que não veem (apenas) com olhos. Dentre elas estão: Regina Célia, Eli, Don Juan, Subcomandante Marcos, Castañeda, Saramago, Skliar, Bavcar e Leidiane. Estas conversas foram fabuladas e narradas neste texto a fim de fazer ploriferar sentidos outros para o "ver" e o "não ver". Para então desvincular a ideia de que a visão está somente atrelada ao pleno funcionamento do olho e que a deficiência visual é a negação do ver.

Mira Capitán, hubo un tiempo, hace mucho tiempo, en que nadie miraba... No es que no tuvieran ojos los hombres y mujeres que se caminaban estas tierras. Tenían de por sí, pero no miraban. Los dioses más grandes, los que nacieron el mundo, los más primeros, de por sí habían nacido muchas cosas sin dejar mero clarito para qué o por qué o sea la razón o el trabajo que cada cosa debía de hacer o de tratar de hacer.

Bueno, el caso es que los dioses primeros, los más grandes, nacieron el mundo, pero no dejaron claro el para qué o el porqué de cada cosa. Y una de estas cosas eran los ojos. ¿Acaso habían dejado dicho los dioses que los ojos eran para mirar? No pues. Y entonces ahí se andaban los primeros hombres y mujeres que acá se caminaron, a los tumbos, dándose

1 Esta dissertação encontra-se disponível em https://drive. google.com/file/d/0B_ot_pIFeUYYalN1M2dMVFFVSEk/view golpes y caídas, chocándose entre ellos y agarrando cosas que no querían y dejando de tomar cosas que sí querían. Así como de por sí hace mucha gente ahora, que toma lo que no quiere y le hace daño, y deja de agarrar lo que necesita y la hace mejor, que anda tropezándose y chocando unos con otros. 0 sea que los hombres y mujeres primeros sí tenían unos sus ojos, sí pues, pero no miraban.

Y así se hubiera seguido todo hasta nuestros días si no es porque una vez pasó algo. Resulta que estaban los dioses primeros, los que nacieron el mundo, los más grandes, haciendo una su bailadera porque agosto era, pues, mes de memoria y de mañana, cuando unos hombres y mujeres que no miraban se fueron a dar a donde estaban los dioses en su fiestadero y ahí nomás se chocaron con los dioses y unos fueron a dar contra la marimba y la tumbaron y entonces la fiesta se hizo puro borlote y se paró la música y se paró la cantadera y pues también la bailadera se detuvo y gran relajo se hizo y los dioses primeros de un lado a otro tratando de ver por qué se detuvo la fiesta y los hombres y mujeres que no miraban se seguían tropezando y chocando entre ellos y con los dioses. Y así se pasaron un buen rato, entre choques, caídas, mentadas y maldiciones.

Ya por fin al rato como que se dieron cuenta los dioses más grandes que todo el desbarajuste se había hecho cuando llegaron esos hombres y mujeres. Y entonces los juntaron y les hablaron y les preguntaron si acaso no miraban por dónde caminaban. Y entonces los hombres y mujeres más primeros no se miraron porque de por sí no miraban, pero preguntaron qué cosa es "mirar". (Subcomandante Marcos, 2016, p. 13).

Meu encontro com este conto zapatista, La historia de las miradas, deu-se por primeira vez pela belíssima voz de Eduardo Galeano. Ele narra esta história; no entanto, a enriquece ainda mais com sua entonação, suas pausas reflexivas e seu olhar que parece penetrar nossa alma. Ouvi-lo foi uma experiência ímpar. Aliás, ouvir histórias tem sido um aprendizado, um prazeroso aprendizado. Atentar-me para o som das palavras e das coisas, para as diferentes texturas que me tocam... para os cheiros ao meu redor, tem sido um aprendizado. Um exercício provocado pela convivência com pessoas que não veem (apenas) com os olhos.

Há pouco tempo, aproximadamente dois anos, tenho me encontrado com quatro pessoas no Instituto Benjamin Constant. Elas tornaram-se cegas ao longo de sua vida e fazem reabilitação nesta instituição para construírem outro modo de produzir a vida. A pergunta nas entrelinhas de praticamente todas as minhas falas com eles era “0 que é ver?". Esta mesma pergunta feita pelos hombres y mujeres más primeros 
fizeram aos dioses primeros, los que nacieron el mundo, los más grandes... E, também, por Carlos Castañeda (1971) a Dom Juan, durante sua estada em Sonora - México.

Ver não é algo simples e muito menos se limita apenas ao funcionamento do olho. Neste complexo jogo abrigam-se questões que talvez a ciência biológica, somente, não dê conta. É necessário "confrontar a rigidez do músculo ocular, esgarçar a abertura enrijecida que seleciona luzes, ângulos, dimensões para ampliar as condições de ver" (Zanella, 2012, p. 172). Contar com outras linguagens, a literatura, o cinema, a música, a poesia. Portanto, esta é a proposta deste trabalho, um convite para uma conversa entre pessoas que não veem (apenas) com os olhos a fim de manter viva uma pergunta: ¿Qué cosa es mirar?

Certa vez, quando assisti ao documentário Janela da alma (Jardim e Carvalho, 2001), saltava-me esta questão. Um documentário brasileiro que, com vários depoimentos de artistas, poetas, músicos, médicos e cineastas, tratava poeticamente do ver e do não ver. Levantando a ideia de que o que olhamos é composto por múltiplas tonalidades, focos e nitidez, pois depende do olho de quem olha, sendo o mesmo janela do corpo, da alma.

Nesta mesma trama havia o depoimento de uma pessoa que dizia enxergar perfeitamente, até que um dia, quando colocou óculos, percebeu o mundo de maneira diferente. 0 que ele via, quando achava que enxergava bem, não era mais a mesma coisa: via a árvore como uma massa marrom (o tronco) e uma massa verde (a copa). No entanto, após colocar os óculos percebeu que no tronco da árvore havia ranhuras e na copa, as folhas com seus inúmeros detalhes. 0 que conseguia enxergar considerava como realidade, mas depois dos óculos tudo aquilo que achava ser verdadeiro, real, único e universal, era apenas o que conseguia ver com seus olhos.

Desde então venho me perguntando, ¿Qué cosa es mirar? Muito embora não queira encontrar uma resposta fechada, acabada e consensual para esta pergunta. Ela vem me fazendo movimentar, a fim de conhecer as múltiplas outras possibilidades desconhecidas que há no jogo do ver. $O$ que está em jogo quando se está a ver? (Kirst, 2003, p. 43). Se os nossos olhos não são os únicos órgãos, ou, melhor dizendo, os únicos dispositivos em agenciamento no ato de ver, que outros dispositivos estão imbricados neste jogo?

Diante deste desejo de conhecer as múltiplas formas de perceber o mundo, comecei a me encontrar com pessoas que não veem (apenas) com os olhos. Em um desses encontros, fomos passear pelo IBC. Eu estava com os olhos vendados e eles - Regina Célia e Eli- conduziam-me. 0 desejo naquele passeio era conhecer a instituição vivida por eles, a partir dos usos que eles faziam daquele lugar. Como eu não tinha experiência em andar de olhos vendados, uma profissional da Orientação e mobilidade nos acompanhou, com certa distância, apenas me vigiando para não tropeçar e cair, pois ali, naquele momento, eu quem precisava de atenção, por não conseguir enxergar.

Todo o meu corpo ainda funcionava, mas com os olhos vendados senti como se a atenção, o ouvir e a dimensão espacial estivessem se reconfigurando. Embora percebesse o mundo também com os outros sentidos, depositava apenas no olhar a função do ver. Esqueci que todo o corpo também estava relacionado no ato de ver. E segui como "los primeros hombres y mujeres que acá se caminaron, a los tumbos, dándose golpes y caídas, chocándose entre ellos" (Subcomandante Marcos, 2016, p. 13).

Durante este passeio a tropeços e chocadas, percebi outra dimensão do visível. Não estava acostumada a me movimentar daquela outra maneira, é um aprendizado lento e árduo reaprender a se movimentar pela cidade sem o recurso visual - pensava comigo mesma-. "Era como se tudo isso estivesse já a diluir-se numa espécie de estranha dimensão, sem direções nem referências, sem norte nem sul, sem baixo nem alto" (Saramago, 1995, p. 15).

Naquele momento eu estava completamente cega. Ficar com os olhos vendados me trouxe tamanho desconforto que havia me esquecido de todos os outros sentidos, tamanha era minha dependência. 0 mesmo percurso que fazia há vários meses se tornou longo, os minutos tornaram-se infindáveis, o tempo tornou-se outro, a dimensão espacial também. Já não era mais a mesma instituição. Andava tão lentamente que, com medo de cair, arrastava os pés. E, a passos miúdos, íamos nós três: seu Eli me guiando e Regina Célia segurando em meu braço esquerdo sendo guiada por mim.

De olhos vendados, não contava com a antecipação ou com a dimensão de profundidade proporcionada pelo olhar, no entanto, percebia com muito mais atenção cada passo que dava. Não andávamos apressadamente e nem a passos largos, íamos devagar quase que apalpando o chão com os pés.

Mudança de piso entre um corredor e outro, lombadas, degraus, desníveis de azulejos, valas, pedrinhas... Passaram a ter mais importância naquela caminhada do que placas e murais de aviso. Outra sensação importante foi o vento. Corria pela nossa nuca como nunca antes houvera feito. Sua direção nos indicava se estávamos ou não indo para o lugar certo. Tantas sensações, e eu sem nenhuma fonte de registro, não estava com a câmera e nem com o meu 
diário. Tudo o que vivemos ficara ali, acontecendo no presente, reverberando efeitos no aqui e agora, os quais se tornam contínuos. Talvez nossa mania de registrar, capturar tudo a nossa volta para que seja postergado, acabe nos cegando.

Don Juan, um bruxo do povoado de Sonora no México, em uma de suas expedições com Carlos Castañeda, a fim de ensiná-lo a ver, lhe disse que uma de suas predileções era ver, mas gostava de ver tudo. Castañeda, seu aprendiz, um antropólogo pesquisador, disse-lhe que também sabia ver tudo. Entretanto Dom Juan lhe contradiz: "Você só olha para a superfície das coisas" (Castañeda, 1971, p. 16).

0 que há neste jogo em que Dom Juan, Regina Célia e Eli nos convida? Que olhar é este que não se atém apenas a decifrar imageticamente o que nossos olhos conseguem captar? 0 que há depois da superfície das coisas?

Os agenciamentos engendrados no ato de olhar modificam o que olhamos? Modificam, ou produzem? Há uma realidade a priori que possa ser vista? Ou será que o visto é efeito destes movimentos, deslocamentos que comportam "linhas de articulação ou segmentaridade, estratos, territorialidades, mas também linhas de fuga, movimentos de desterritorialização e desestratificação?" (Deleuze e Guattari, 2011, p. 18). É na relação com o outro que construímos mundos? E estes mundos mudam ante uma nova relação, um novo outro... Um novo eu? 0 ato de olhar, atravessado por todas estas linhas que nos compõem, é também um modo de construir mundos. É agenciamento!

Assim como há muitos olhos, e de todos os tipos, "de todos los colores y de todos los tamaños, los había de diferentes formas. Había ojos redondos, rasgados, ovalados, chicos, grandes, medianos, negros, azules, amarillos, verdes, marrones, rojos y blancos" (Subcomandante Marcos, 2016, p. 13). Há também muitas pessoas, com múltiplos modos de ser e de estar no mundo. Dando aos seus modos de ver muitas tonalidades, ângulos, perspectivas e profundidades. Talvez o jogo do ver seja outra coisa que vá além da função fisiológica do olho.

"Eu bem sabia que a nossa visão é um ato poético do olhar" (Barros, 2013, p. 428). Em outras palavras, no jogo do olhar implicamos os nossos desejos, nossos medos, sonhos, certezas. De modo que tudo aquilo que nos passa, nos atravessa e nos modifica, o que se torna saber de experiência (Larrosa, 2014), compõe o jogo do ver. Seria, portanto, muito reducionista se esgotasse a visão apenas às pessoas que tenham o "sadio" funcionamento fisiológico do olho, do sistema ocular. Entretanto, durante minhas experiências ao encontrar-me com pessoas que não veem (apenas) com os olhos, percebi que a visão não se esgota no funcionamento do olho físico. Então, mais uma vez retomo a pergunta: ¿Qué cosa es mirar?

Certo dia, Regina Célia, Eli, Joaquim, Sandra e eu, passeávamos pelo estacionamento do IBC. Já era a parte da tarde, passava das 14:00hs. Nesta parte do dia o pátio fica mais vazio, então podemos perceber com muito mais ênfase o som da natureza. Indo passo a passo, agora não mais com a venda nos olhos, seguia junto com eles, quando Eli interrompe a caminhada, vira-se para mim e diz: Olha! Um Bem-te-vi! Bem-te-vi... Bem-te-vi... (cantarola imitando o som do pássaro). Paramos e rapidamente peguei meu celular para fotografar a fim de registrar aquele momento, mas não via o pássaro, embora Eli estivesse, incessantemente, apontando a direção, eu não conseguia visualizar aquela ave. Com um pouco de frustração desisti de procurá-lo e seguimos o nosso passeio. Por que não o vi? Pensava comigo mesma. Meus olhos não deram conta daquilo que queria ver. Por vezes não vemos o que queremos e, por muitas vezes, não vemos que não vemos.

"[Willian Blake] afirmava que ele não [vemos] com os olhos, mas através deles. Isto significa que ver (...) equivale a alcançar a compreensão de algo, utilizando todas as explicações, metáforas, parábolas etc. com que contamos" (Foerster, 1996, p. 59). Há pessoas que, mesmo não tendo os olhos convencionais e convencionados, conseguem ver coisas que não são tão fáceis de serem captadas quando olhamos apenas com eles.

Así aprendieron estos hombres y mujeres que se puede mirar al otro [...] Supieron también que se puede mirar adentro del otro y ver lo que siente su corazón. Porque no siempre el corazón se habla con las palabras que nacen los labios. Muchas veces habla el corazón con la piel, con la mirada o con pasos se habla. También aprendieron a mirar a quien mira mirándose, que son aquellos que se buscan a sí mismos en las miradas de otros. Y supieron mirar a los otros que los miran mirar. (Subcomandante Marcos, 2016, p. 13. Grifo meu).

Cotidianamente aprendemos a olhar. 0 mundo a nossa volta, as mídias, os meios de comunicação nos ensinam o que olhar e como olhar. Entretanto desaprendemos a ver as coisas como necessitam ser olhadas. Olhamos de maneira distanciada. Antecipamo-nos por que vemos, e se já vemos não precisamos tocar para saber o que é, aliás, de antemão fazemos uma série de preconceitos e definições para o que olhamos, atribuindo-lhe juízo.

A antecipação, nos distancia do que vemos. Segundo ele, os olhos são instrumentos da distância. Não 
nos permitimos ao toque, ao afeto. 0 'contato' - a contiguidade, a fricção, o encontro e a colisão-é a modalidade fundamental do afeto (Nancy, 2007, como citado em Skliar, 2011). Se nos antecipamos criando sobre o outro uma série de preconceitos, não nos afetamos e muito menos permitimo-nos nos afetar, e, por conseguinte, não vemos.

Olhamos, mas não vemos.

Por que, vendo, cegamos?

0 que nos impede de ver?

Lembro-me de Dom Juan, que em um dos escritos de Castañeda disse: "que eu estava com tudo pronto e que, no entanto, minha mania sempre me cegava no final. —Não há nada para entender. Tal faculdade é apenas uma coisa muito pequena, muito pequena mesmo-disse ele" (Castañeda, 1971, p. 294).

A mania de explicação, a fixação por encontrar um entendimento consensual para as coisas e trazê-las para o plano da racionalidade, da claridade... Estes artifícios do homem moderno que sempre cegavam Castañeda, também vem nos cegando até hoje. Nós, sujeitos modernos, lógicos e racionais, com sua cabeça pensante separada do corpo desejante, buscamos incessantemente nos informar, de forma clara e nítida, sobre que ocorre a nossa volta, "cada vez sabemos mais, cada vez estamos mais bem informados, porém, (...) o que conseguimos é que nada [nos] aconteça" (Larrosa, 2014, p. 19). Estamos sempre em dívida com as informações e com o tempo, buscamos sempre nos manter atualizados, acumulamos informação, e, no entanto, não dispomos de tempo para que alguma coisa nos aconteça. 0 tempo, moeda valiosa em nossa sociedade, tem se tornado cada vez mais escassa.

Ver com os olhos, talvez, tenha sido o meio mais rápido que desenvolvemos para nos apropriarmos do mundo. Não temos tempo para perceber as coisas, situações ou pessoas através de outros sentidos. Antecipar-se pelo que conseguimos captar com os olhos tem sido o modo que consideramos mais objetivo.

Olhamos e rapidamente já sabemos o que é, e tão logo decretamos nosso juízo sobre o que vemos. No entanto, a obsessão pela opinião também anula nossas possibilidades de experiência, também faz com que nada nos aconteça (Larrosa, 2014, p. 20). Não tocamos, não cheiramos, não nos perguntamos sobre $o$ que vemos, pois, se já vemos, entendemos tolamente que já conhecemos. Nosso olhar: o preconceito primeiro dos sentidos.

Os objetos fazem parte do meu corpo, tenho muitos objetos em casa, pedras das ruas de Praga, de minhas visitas ao mundo. Também exprimem a materialidade do mundo, porque, quando se toca alguma coisa, se toca de verdade, enquanto o olhar imprime distância. (Coelho, 2006, p. 23).

Ele nos distancia daquilo que olhamos se considerarmos o olhar apenas um ato contemplativo. Poderia ele então nos impedir de ver? Ver por outros meios, por outros sentidos?

Em uma sociedade em que o predomínio da visão subsiste, e que é estimulada constantemente através dos meios urbanos, de sua arquitetura, organização e mídias,

[...] passar os olhos sobre as inúmeras imagens dispersas no centro urbano e nos meios de comunicação provoca a dispersão e não o centramento. Ao ser saturado de "luminosidade", o indivíduo contemporâneo esquece de pensar o que há por trás desta luz, perde aos poucos a sensibilidade para perceber tudo aquilo que não é iluminado, 0 que não é "evidente". (Coelho, 2006, p. 36).

Como diz Saramago (1995), esse excesso de luminosidade e de informação, nos deixou cegos.

En una época donde todo se ha vuelto visible o posible de ser visto, quizá lo visual sea incontrolable, indescifrable, a la vez que cotidiano y familiar. Hay tanto un exceso y saturación frente a la imagen como una sensación de anorexia visual: frente a la pluralidad y multiplicidad de imágenes estamos debilitados para poder ver, para poder entender y para poder producir algo con los efectos de lo apenas visto. (Skliar, 2009, s/p.)

Diante de tantas informações visuais, deixamos de olhar como se fosse a primeira vez. Alimentamos um olhar domesticado, acostumado a ver apenas o que já se sabe (Larrosa, 2006). Eis a cegueira luminosa sobre a qual Saramago nos alerta. "Es como si todo lo que vemos no fuera otra cosa que el lugar sobre el que proyectamos nuestra opinión, nuestro saber y nuestro poder, nuestra arrogancia, nuestras palabras y nuestras ideas, nuestras conclusiones" (Larrosa, 2006, p. 119). 0 que vemos a nossa volta é apenas uma constatação de nossas crenças e certezas que produzimos ao longo da vida, de modo que somente conseguimos ver aquilo que conhecemos. Certa vez,

Castañeda foi ao povoado de Sonora, no México, para conhecer um bruxo chamado Don Juan, a quem pediu que o ensinasse a ver. Assim Don Juan interna-se com Castañeda, no meio da selva mexicana. Caminham uma ou duas horas e, de repente, Don Juan exclama: “Olha, olha o que há aí! Viste?”. Castañeda lhe responde: "Não... não o vi". Continuam caminhando e, uns dez minutos mais tarde, Don Juan volta a deter-se e exclama: "Olha, olha aí! Viste?”. Castañeda olha e responde: “Não... Não vi nada”. “Ah!”, é 
a lacônica resposta de Don Juan. Seguem sua marcha e volta a acontecer a mesma coisa duas ou três vezes, mas Castañeda nunca vê nada; até que, enfim, Don Juan encontra a solução: "Agora entendo qual é o teu problema!", lhe disse: “Tu não podes ver o que não podes explicar. Trata de esquecer de tuas explicações e começarás a ver". (Foerster, 1996, p. 67).

0 mundo que vemos é o mundo que criamos com nossas singularidades. Este mundo está atravessado por nossas experiências, as quais não são apenas simples vivências, mas sim os acontecimentos que nos deslocam, forçando-nos a pensar o que jamais poderíamos pensar, a ver o que jamais poderíamos ver e a sentir o que jamais poderíamos sentir.

Em outro encontro com pessoas que não veem (apenas) com os olhos, perguntei-lhes se poderiam me dizer algo desse novo modo de estar na vida. Em poucas palavras, Seu Joaquim me diz que, desde então, passou a enxergar mais que antes.

Acho que estou enxergando muito mais que antes. Antigamente, muita coisa passava do meu lado, na minha frente, e eu não via nada, não entendia nada. E agora estou vendo muita coisa que antes nem sabia que existia. Por exemplo, quando estou sozinho na rua, muitas pessoas vêm me ajudar, até mesmo pessoas mais idosas que eu, com menos mobilidade que eu. Então, passei a enxergar solidariedade.

(Trecho da conversa durante um encontro).

A fala de Seu Joaquim faz proliferar olhares. Seu novo modo de estar no mundo lhe provocou um estado de atenção para pequenos gestos que antes não tinha. Talvez o excesso de estímulos visuais espalhados a nossa volta provoque em nós certa acomodação do olhar, a qual sempre nos condiciona a olhar e vermos sempre nas mesmas direções, as mesmas cenas com os mesmos ângulos. Vemos e vemos demasiada e incansavelmente as mesmas coisas todos os dias; damos a tudo o que vemos as mesmas, demasiadas e incansáveis, explicações todos os dias.

Entretanto, Skliar e Seu Joaquim, e tantas outras pessoas que não veem (apenas) com os olhos, nos convidam a desver o mundo, a "multiplicar las formas de mirar, [a] multiplicar las posibilidades de mirar todo aquello que las imágenes producen"(Skliar, 2009, s/p). Não se trata de produzir uma outra maneira de ver, mas, sim, de desnaturalizar este mundo de imagens que nos cerca, pensar no que vemos e nos perguntarmos por isso que vemos, e, também, pelo que não vemos e por que não o vemos.

Perguntar-se pelo que se vê...

Quando no caminho para casa, no dia em que assisti pela primeira vez ao documentário Janela da
Alma, me vi questionando tudo a minha volta. Dentro do ônibus estranhava as informações que lia, as tonalidades das cores, o formato das janelas, as abria e fechava a fim ver a parte externa com e sem o filtro do vidro. Já não confiava plenamente no que os meus olhos me diziam ser real. "O abandono do lugar me abraçou com força. E atingiu meu olhar para toda a vida. Tudo que conheci depois veio carregado de abandono" (Barros, 2013, p. 418). "Então era preciso desver o mundo para sair daquele lugar imensamente e sem lado" (p. 430).

0 encontro com o filme, com o poeta rupestre, com Seu Joaquim, Regina Célia e Eli, ainda reverbera provocações. Provocam outros encontros e outros encontros que mantêm pulsante a pergunta feita no início deste texto:

\section{¿Qué cosa es mirar?}

Supieron también que se puede mirar adentro del otro y ver lo que siente su corazón. Porque no siempre el corazón se habla con las palabras que nacen los labios. Muchas veces habla el corazón con la piel, con la mirada o con pasos se habla. (Subcomandante Marcos, 2016, p. 13).

Como Seu Joaquim, que passou a enxergar solidariedade, como o poeta Manoel de Barros quando diz que "a visão é um ato poético do olhar" (2013, p. 428), ou até recurso da imaginação, tão logo percebemos que a "falta da visão" - como assim considera o paradigma médico-clínico em relação à cegueira- está relacionada à atenção, ou seja, o "não ver" nos demanda um estado de atenção muito maior do que quando olhamos com os olhos. Sendo assim, abandonarmos os olhos, ainda que por alguns instantes, talvez seja um exercício de disponibilidade a conhecer e fazer existir muitos mundos-outros.

Deste modo, meu convite - e de muitas outras pessoas que, também, não veem (apenas) com os olhos- é provocar o nosso pensamento a pensar sobre o que consideramos ver, enxergar, olhar, não ver, cegar. Mas não é a cegueira fisiológica, aquela que afeta o funcionamento biológico do sistema ocular. Trata-se de uma outra cegueira. Na qual estamos imersos. Diga-se de passagem, que os nossos olhos "parecem sãos, a íris apresenta-se nítida, luminosa, a esclerótica branca, compacta como porcelana" (Saramago, 1995, p. 12). Contudo, não vemos. Por que não? Já que tudo se apresenta aparentemente bem? Isso já não é supostamente o suficiente?

Acreditava que a cegueira era apenas a ausência de luz, a qual se "limitava a cobrir a aparência dos seres e das coisas, deixando-os intactos por trás do seu véu negro" (Saramago, 1995, p. 16). Todavia, no 
encontro com pessoas que não veem (apenas) com os olhos, percebi-me mergulhada "numa brancura tão luminosa, tão total, que devorava, mais do que absorvia, não só as cores, mas as próprias coisas e seres, tornando-os, por essa maneira, duplamente invisíveis" (p. 16).

Não via o que Regina Célia, Eli, Joaquim e Sandra traziam consigo para encontrar comigo, ignorava seus desejos e expectativas. Não via o bem-te-vi em meio os galhos da árvore. Não percebia o vento que tocava a minha nuca todas as vezes que passava por aquele corredor, não via nada disso. Não via, e muito menos percebia que estava cega. Não via que não via (Foerster, 1996). A minha visão não estava cheia de pontos cegos, muito menos não fora acometida pela ausência de luz. Apenas seguia vendo e acreditando que conseguia ter acesso a toda realidade por meio dos olhos.

Estamos imersos em uma imensidão de imagens, de palavras, de saberes, opiniões, ideias e conclusões que nos cegam. $E$ as pessoas que não veem (apenas) com os olhos? Seriam elas, também, propensas à cegueira luminosa de Saramago? Se considerarmos o olhar como preconceito primeiro dos outros sentidos, a cegueira seria condição primeira para vermos além do visível? Penso que não cegamos, penso que estamos cegos, cegos que veem, cegos que, vendo, não veem
(Saramago, 1995, p. 310). 0 que não vemos quando vemos? O que vemos quando não vemos?

Nossos olhos conseguem captar tudo o que nos rodeia? Seria ilusória a sensação de que vemos tudo? 0 homem da sociedade da informação, um homem atento a tudo! Ligado a tudo que lhe passa... Como se tivesse mil olhos. Ou, talvez, cem olhos como os de Argus Panoptes - “(aquele) que tudo vê"- Símbolo da mitologia grega para a vigilância. Um gigante que nunca fechava por completo seus olhos, enquanto 50 dormiam, os outros 50 estavam acordados. Nada passava despercebido!

Fiquei curiosa por conhecer Argus. No afã de saciar este desejo, pesquisei imagens que o descrevessem, quando me deparo com a seguinte imagem.

Seria ela a imagem de Argus? Imaginava que todos os cem olhos estivessem no rosto. Ou será esta imagem uma subversão do gigante Panoptes? Um corpo todo feito por olhos?

Ou um corpo que agencia todas as percepções, metáforas e experiências para compor o jogo do ver? Uma imagem que compõe com o que Foerster (1996) nos traz como sentido outro para o ver, trazendo a percepção do corpo como um todo. Que outras imagens nos são possíveis quando implicamos todos os outros sentidos no ato de ver, e não somente o sentido da visão?

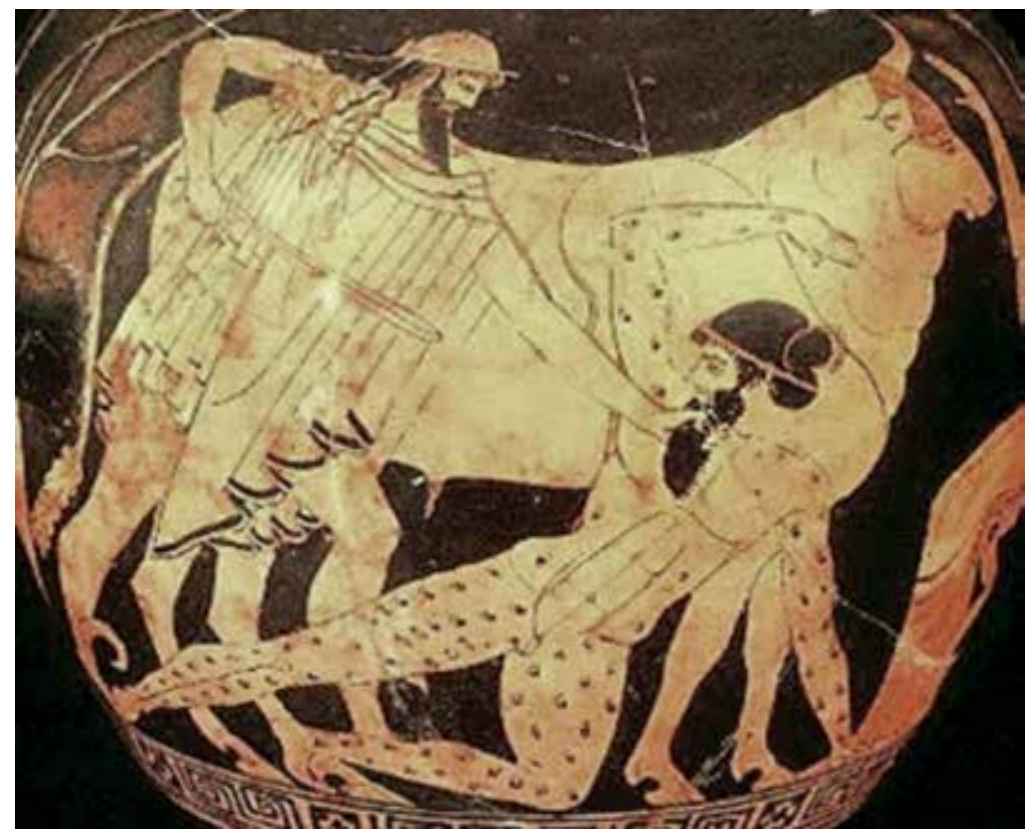

Imagem 1. Hermes e Argos Panoptes

Fonte: https://mithologywithapurpose.files.wordpress.com/2007/07/hermes_argospanoptes.jpg. 
Foerster (1996, p. 60) nos inquieta afirmando que "não vemos que não vemos". Temos um ponto cego, mas não sabemos, pois neste ponto não há um vácuo escuro, apenas não conseguimos enxergar determinados objetos. Vejamos o exercício que ele propõe em seu artigo e que considero importante fazê-lo aqui.

Observe as duas figuras abaixo:
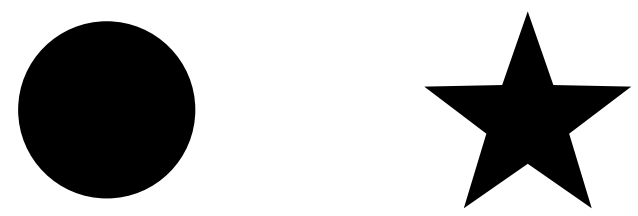

Segure a folha com a mão direita, tape o olho esquerdo com a mão esquerda. Olhando para a estrela com o olho direito aberto, movimente a folha para frente e para trás, de um lado a outro, na altura dos olhos, numa distância de aproximadamente $20 \mathrm{ou}$ $30 \mathrm{~cm}$. 0 que você vê? Certamente, haverá um momento em que o círculo não mais aparecerá. Há uma explicação médica para isso, entretanto, não quero me ater a essa discussão diante de um outro ponto tão importante quanto: a dimensão provisória, temporal e subjetiva de nossa visão.

O que me chama a atenção para este fenômeno é pelo fato de que não percebemos que não vemos. "Se alguém olha ao seu redor em todas as direções com um olho, depois com os dois, a seguir com o esquerdo, logo depois com o direito, vê sempre um campo visual sem solução de continuidade, sem interrupções" (Foerster, 1996, p. 60). Não há interrupção de pontos cegos perambulando pelas cenas captadas pelos nossos olhos, deixando-nos com a ilusória sensação de que estamos vendo tudo.

Não vemos que não vemos e seguimos arrogantemente cheios de nós mesmos, na tola certeza de que nos tornamos Argus. A Modernidade e suas instituições (incluída a Universidade como Escola) acreditam ter se tornado essa criatura de 100 olhos. Estamos acorrentados às nossas razões, às nossas explicações, ao demasiado visto, ao por demais conhecido. É preciso desconhecer para ver! (Des)automatizar nosso olhar a fim de vermos as coisas como se fosse a primeira vez (Skliar, 2009).

Trata-se de "liberar los ojos, de aprender a mirar con ojos de niños. El adulto [porta] una mirada disciplinada y normalizada, desde de la que no hay nada que ver que no haya sido visto antes" (Larrosa, 2006, p. 118). Trata-se, portanto, de aprender a olhar com olhos de surpresa, de estranhamento. Talvez los dioses más grandes, los que nacieron el mundo, los más primeros, não tenham deixado meio clarito todas as coisas que conseguimos ver com os olhos ou sem eles.
Por isso, seguimos caminhando, a los tumbos, dándose golpes y caídas, chocándose e perguntando-se: ¿Qué cosa es mirar?

\section{Referências}

Barros, M. (2013). Poesia completa. São Paulo: LeYa.

Castañeda, C. (1971). Uma estranha realidade (9. Ed.). Rio de Janeiro: Record.

Coelho, A. (2006). José Saramago e Evgen Bavcar: os paradoxos do olhar (Tese de mestrado, Universidade Federal de Pernambuco CAC). Departamento de Letras. Pernambuco.

Deleuze, G. e Guattari, F. (2011). Mil platôs: capitalismo e esquizofrenia 2. (vol. 1, 2. ㄹ Ed.). São Paulo: 34.

Foerster, H. (1996). Visão e conhecimento: disfunções de segunda ordem. Em D. F. Schnitman (Ed.). Novos paradigmas, cultura e subjetividade. (pp. 59-74) Porto Alegre: Artes Médicas.

Jardim, J. e Carvalho, W. (Director). (2001). Janela da alma. [Película cinematográfica]. Brasil: Copacabana Filmes.

Kirst, P. (2003). Redes do olhar. Em T. Fonseca e P. Kirst (Eds.). Cartografias e devires: a construção do presente. (pp. 43-52) Porto Alegre: UfRGs.

Larrosa, J. (2014). Tremores: escritos sobre experiência. Belo Horizonte: Autêntica.

Larrosa, J. (2006). Una lengua para la conversación. Revista Educación y Pedagogía, 18, 29-42.

Saramago, J. (1995). Ensaio sobre a cegueira. São Paulo: Cia. das Letras.

Skliar, C. (2009). Educar la mirada. Revista Sin Puntero. Recuperado de http://laescuelaylosjovenes.blogspot. com.br/2010/02/educar-la-mirada.html. Em 17 fev.2014.

Skliar, C. (2011). Conversar e conviver com os desconhecidos. Em H. A. da Fontoura (Eds.). Políticas Públicas, Movimentos Sociais: Desafios à Pós-graduação em Educação em suas múltiplas dimensões. (pp. 27-37) Rio de Janeiro: ANPED Nacional. Recuperado de http://www. fe.ufrj.br/anpedinha2011/livro3.pdf. Em: 25 mai.2015.

Subcomandante Marcos. (2016). La historia de las miradas. Los otros cuentos: relatos del subcomandante Marcos. Comunidades zapatistas. Recuperado de http://www. redchiapas.org/proyectos/los-otros-cuentos/.

Zanella, A. (2012). Olhar. Em M. Fonseca, M. do Nascimiento e C. Maraschin (Eds.).Pesquisarna diferença: umabecedário (pp. 169-172). Porto Alegre: Sulina 


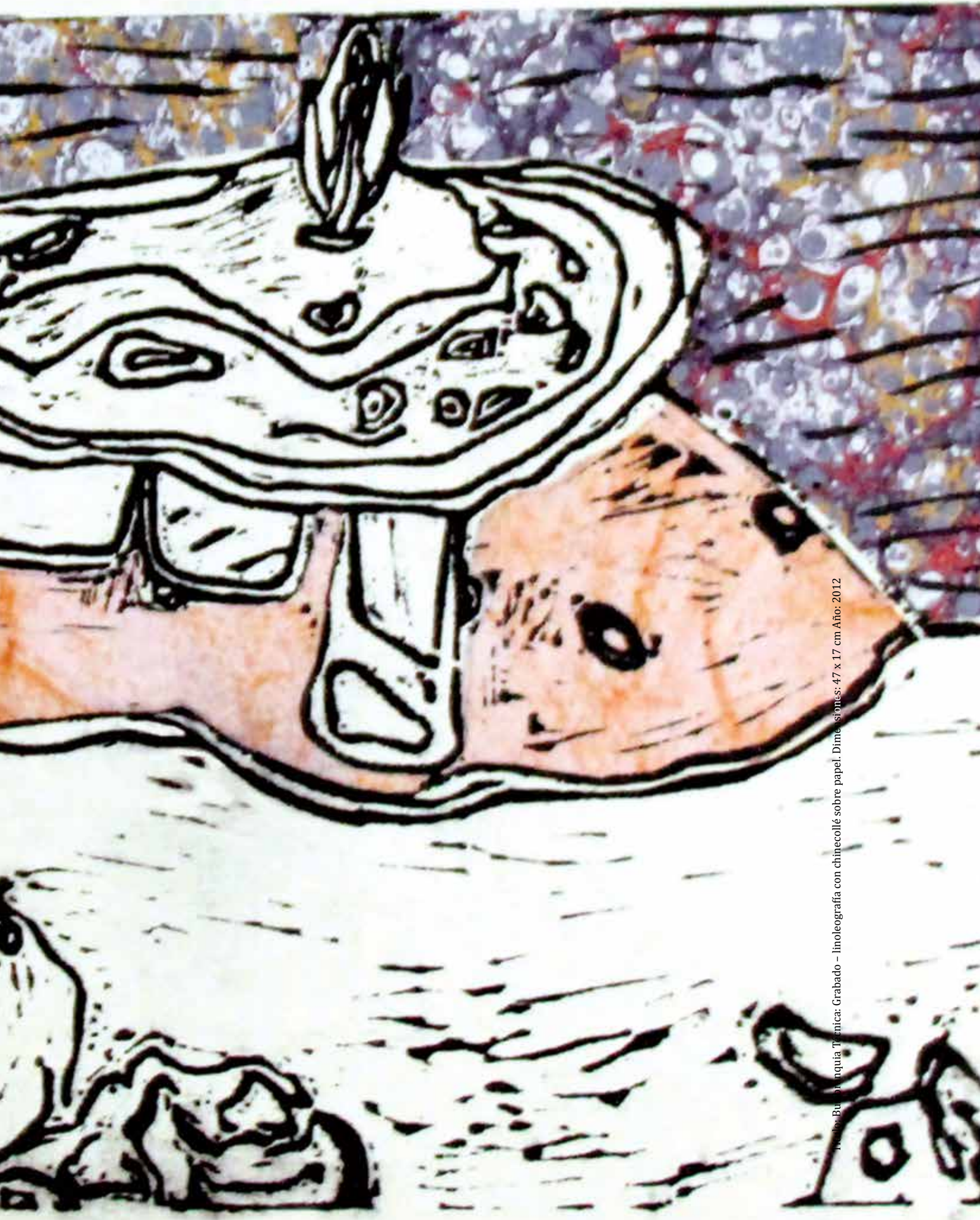

